\title{
Synthesis and Antibacterial Activity of Some Derivatives of 2-Methylbenzimidazole Containing 1,3,4-Oxadiazole or 1,2,4-Triazole Heterocycle
}

\author{
Cong Nguyen Tien, ${ }^{1}$ Duc Tran Thi Cam, ${ }^{1}$ Ha Bui Manh, ${ }^{2}$ and Dat Nguyen Dang ${ }^{3}$ \\ ${ }^{1}$ Department of Chemistry, Ho Chi Minh City University of Education, Ho Chi Minh 700000, Vietnam \\ ${ }^{2}$ Department of Environmental Science, Sai Gon University, Ho Chi Minh 700000, Vietnam \\ ${ }^{3}$ Department of Chemistry, Hanoi University of Education, Hanoi 100000, Vietnam \\ Correspondence should be addressed to Ha Bui Manh; manhhakg@yahoo.com.vn
}

Received 4 November 2015; Revised 18 December 2015; Accepted 20 December 2015

Academic Editor: Liviu Mitu

Copyright ( 2016 Cong Nguyen Tien et al. This is an open access article distributed under the Creative Commons Attribution License, which permits unrestricted use, distribution, and reproduction in any medium, provided the original work is properly cited.

5-[(2-Methyl-1H-benzimidazol-1-yl)methyl]-1,3,4-oxadiazole-2-thiol or 5-[(2-methyl-1H-benzimidazol-1-yl)methyl]-4-(4-methylphenyl)-1,2,4-triazol-3-thiol which were prepared starting from 2-methylbenzimidazole in the reaction with appropriate $N$-aryl2-chloroacetamides afforded two series of $N$-aryl-2-\{5-[(2-methyl-1H-benzimidazol-1-yl)methyl]-1,3,4-oxadiazol-2-yl\}sulfanylacetamides and $N$-aryl-2-\{5-[(2-methyl-1H-benzimidazol-1-yl)methyl]-4-(4-methylphenyl)-4H-1,2,4-triazol-3-ylthio $\}$ acetamides, respectively. The structures of the compounds were elucidated on the basis of IR, MS, ${ }^{1} \mathrm{H}-\mathrm{NMR}$, and ${ }^{13} \mathrm{C}-\mathrm{NMR}$ spectral data. The compounds containing 1,3,4-oxadiazole or 1,2,4-triazole heterocycle also were tested for their antimicrobial activity against bacteria, mold, and yeast.

\section{Introduction}

Benzimidazole and its derivatives are important bioactive molecules with a wide range of activities including antimicrobial, antifungal, antiparasitic, antiviral, anticancer, anti-inflammatory, antioxidant, and antihypertensive activities $[1,2]$. Some heterocyclic compounds containing 2-methylbenzimidazole nucleus have been synthesized and evaluated for biological activities [3-11]. Some five-membered heterocycles have been given a great attention to the medicinal chemists; for example, oxadiazole derivatives are well known to have anti-inflammatory, anticonvulsant, anti-tubercular, and antimicrobial activities [12]; triazole nucleus are known to possess antimicrobial and fungicidal properties [13]. Moreover, in recent times, some acetamides derived from benzimidazole attached to oxadiazole heterocycle $[14,15]$ or triazole heterocycle [16] exhibited promising biological activities.

In view of these observations, some new compounds (2-methylbenzimidazole derivatives bearing 1,3,4-oxadiazole or 1,2,4-triazole heterocycle) have been synthesized. Their antibacterial and antifungal potential were also evaluated as a continuation of our research on antimicrobial compounds [17].

\section{Materials and Methods}

All starting materials were purchased from Merck and used without purification. Melting points were measured in open capillary tubes on a Gallenkamp melting point apparatus.

IR spectra were recorded on FTIR-8400S-SHIMADZU spectrometer using $\mathrm{KBr}$ pellets. ${ }^{1} \mathrm{H}$-NMR spectra were recorded on a Bruker Avance spectrometer at $500 \mathrm{MHz}$ using a DMSO- $\mathrm{d}_{6}$ as a solvent and tetramethylsilane (TMS) as an internal standard $(0.00 \mathrm{ppm})$, and ${ }^{13} \mathrm{C}$-NMR spectra were recorded at $125 \mathrm{MHz}$. The spin-spin coupling constants $(J)$ are given in Hz. Peak multiplicity is reported as s (singlet), $\mathrm{d}$ (doublet), dd (double-doublet), $\mathrm{t}$ (triplet), q (quartet), $\mathrm{m}$ (multiplet), and br (broad). The MS spectra were recorded 


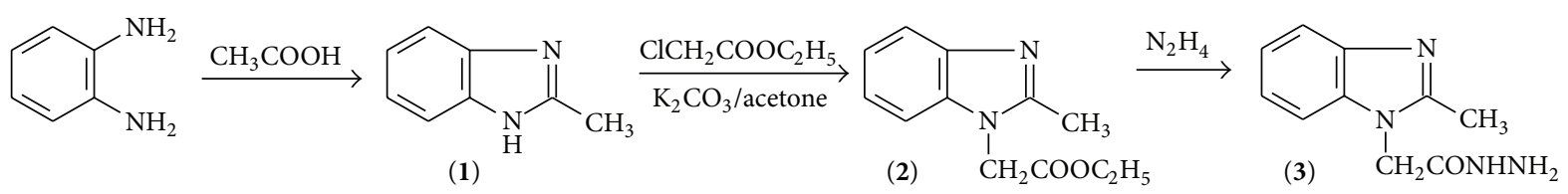

FIGURE 1: Synthetic route for preparation of 2-(2-methylbenzimidazol-1-yl)acetohydrazide (3).

on a Bruker micrOTOF-Q 10187 (a) spectrometer or on an Agilent 6490 (b) spectrometer.

2-Chloroacetamides were synthesized according to Ganguly et al. [18], using the reaction of commercially available 2-chloroacetyl chloride and substituted aniline. The melting point of the prepared 2-chloroacetamides is similar to previous reports $[18,19]$.

2-(2-Methylbenzimidazol-1-yl)acetohydrazide (3) was used as the key intermediate for further synthesis prepared according to reported methods $[3-8,11,16]$, starting from phenylene-1,2-diamine and acetic acid via 2-methylbenzimidazole (1) and then ethyl (2-methylbenzimidazol-1-yl)acetate (2) as shown in Figure 1.

2.1. 2-Methyl-1H-benzimidazole (1). Yield 78\%; mp 174$176^{\circ} \mathrm{C}$ (literature [6]: 176-178 $\left.\mathrm{C}\right)$; IR $\left(\nu, \mathrm{cm}^{-1}\right): 3063,2995(\mathrm{C}-$ $\mathrm{H}), 1622(\mathrm{C}=\mathrm{N}$ and $\mathrm{C}=\mathrm{C})$.

2.2. Ethyl (2-Methylbenzimidazol-1-yl)acetate (2). Yield 64\%; $\mathrm{mp} 114^{\circ} \mathrm{C}$ (literature $\left.[6,9]: 248-250^{\circ} \mathrm{C}\right), \operatorname{IR}\left(\nu, \mathrm{cm}^{-1}\right): 1720$ $(\mathrm{C}=\mathrm{O}$ ester $), 1613(\mathrm{C}=\mathrm{N}) ;{ }^{1} \mathrm{H}-\mathrm{NMR}(\delta, \mathrm{ppm}): 6.69-7.71(\mathrm{~m}$, $4 \mathrm{H}, \mathrm{ArH}), 4.21$ (q, $2 \mathrm{H}, \mathrm{CH}_{2} \mathrm{CH}_{3}$ ), 3.67 (s, $2 \mathrm{H}, \mathrm{HrCH}_{2}$ ), 2.92 (s, $\left.3 \mathrm{H}, \mathrm{HrCH}_{3}\right), 1.32\left(\mathrm{t}, 3 \mathrm{H}, \mathrm{CH}_{2} \mathrm{CH}_{3}\right)$.

2.3. 2-(2-Methyl-1H-benzimidazol-1-yl)acetohydrazide (3). Yield 68\%; mp 191-192 ${ }^{\circ} \mathrm{C}$ (literature [9]: 190-192 $\left.{ }^{\circ} \mathrm{C}\right)$; IR ( $\nu$, $\left.\mathrm{cm}^{-1}\right): 3306(\mathrm{~N}-\mathrm{H}), 1658(\mathrm{C}=\mathrm{O}) ;{ }^{1} \mathrm{H}-\mathrm{NMR}(\delta, \mathrm{ppm}): 9.51(1 \mathrm{H}$, s, NH), $7.51\left(1 \mathrm{H}, \mathrm{d},{ }^{3} \mathrm{~J}=7.5, \mathrm{Ar}-\mathrm{H}\right), 7.39\left(1 \mathrm{H}, \mathrm{d},{ }^{3} \mathrm{~J}=7.5, \mathrm{Ar}-\mathrm{H}\right)$, $7.14(2 \mathrm{H}, \mathrm{m}, \mathrm{Ar}-\mathrm{H}), 4.33\left(2 \mathrm{H}, \mathrm{s}, \mathrm{NH}_{2}\right), 4.79\left(2 \mathrm{H}, \mathrm{s}, \mathrm{HrCH}_{2}\right)$, $2.50\left(3 \mathrm{H}, \mathrm{s}, \mathrm{HrCH}_{3}\right)$.

The synthetic route for the preparation of the target compounds from hydrazide (3) is presented in Figure 2.

2.4. Synthesis of 5-[(2-Methyl-1H-benzimidazol-1-yl)methyl]1,3,4-oxadiazole-2-thiole (4). A mixture of compound 3 $(3.06 \mathrm{~g}, 15 \mathrm{mmol})$ and potassium hydroxide $(0.84 \mathrm{~g}, 15 \mathrm{mmol})$ in ethanol $(40 \mathrm{~mL})$ was added to $4.5 \mathrm{~mL}$ of carbon disulfide and refluxed for 10 hours. The solvent was evaporated and the residue was dissolved in $50 \mathrm{~mL}$ water and then acidified with dilute hydrochloric acid. The formed precipitate was filtered off, washed with water, and recrystallized from mixture of ethanol and water to give 4 as pale yellow solid. Yield 55\%; $\mathrm{mp} 175-176^{\circ} \mathrm{C}$ (literature [9]: $\left.175-176^{\circ} \mathrm{C}\right)$; IR $\left(\nu, \mathrm{cm}^{-1}\right): 2989$ $(\mathrm{C}-\mathrm{H}), 1608$ (C=N, C=C). ${ }^{1} \mathrm{H}-\mathrm{NMR}(\delta, \mathrm{ppm}): 7.57(2 \mathrm{H}, \mathrm{dd}$, ${ }^{3} J_{1}={ }^{3} J_{2}=7.0$, Ar-H $), 7.22(2 \mathrm{H}, \mathrm{m}, \mathrm{Ar}-\mathrm{H}), 5.68\left(2 \mathrm{H}, \mathrm{s}, \mathrm{CH}_{2}\right)$, $3.44(1 \mathrm{H}, \mathrm{br}, \mathrm{SH}), 2.57\left(3 \mathrm{H}, \mathrm{s}, \mathrm{HrCH}_{3}\right)$.
2.5. General Procedure for Synthesis of N-Aryl-2-\{5-[(2-meth$y$ l-1H-benzimidazol-1-yl)methyl]-1,3,4-oxadiazol-2-yl $\}$ sulfanylacetamides $(\mathbf{5} \boldsymbol{a}-\boldsymbol{b})$. An appropriate solution of $N$-aryl chloroacetamide $(2.5 \mathrm{mmol})$ and anhydrous $\mathrm{K}_{2} \mathrm{CO}_{3}(0.28 \mathrm{~g}$, $\sim 2 \mathrm{mmol}$ ) were added to a stirred solution of compound 4 $(0.5 \mathrm{~g}, 2 \mathrm{mmol})$ in $30 \mathrm{~mL}$ of acetone at room temperature. After the addition, the reaction was stirred for further 3 hours at $60^{\circ} \mathrm{C}$. The precipitated solid was filtered, dried, and recrystallized from suitable solvents to afford pure acetamides $\mathbf{5 a - b}$.

2.6. 2-\{5-[(2-Methyl-1H-benzimidazol-1-yl)methyl]-1,3,4-oxadiazol-2-ylthio\}-N-phenylacetamide (5a). It is a white power which is recrystallized from a mixture of dioxane and water. Yield: 69\%; $\mathrm{mp} 150-151^{\circ} \mathrm{C}$. IR $\left(\nu, \mathrm{cm}^{-1}\right): 3180(\mathrm{~N}-\mathrm{H}), 2924(\mathrm{C}-$ $\mathrm{H}), 1676(\mathrm{C}=\mathrm{O}), 1599$ and $1562(\mathrm{C}=\mathrm{N}, \mathrm{C}=\mathrm{C}) ;{ }^{1} \mathrm{H}-\mathrm{NMR}(\delta$, ppm): 10.34 (1H, s, N-H), 7.52 (4H, m, Ar-H), 7.31 (2H, dd, $\left.{ }^{3} J_{1}=7.0,{ }^{3} J_{2}=8.0 \mathrm{~Hz}, \operatorname{Ar}-\mathrm{H}\right), 7.17(2 \mathrm{H}, \mathrm{m}, \mathrm{Ar}-\mathrm{H}), 7.07(1 \mathrm{H}$, $\left.\mathrm{t},{ }^{3} J=7.5, \mathrm{Ar}-\mathrm{H}\right), 5.79\left(2 \mathrm{H}, \mathrm{s}, \mathrm{CH}_{2}\right), 4.25\left(2 \mathrm{H}, \mathrm{s}, \mathrm{SCH}_{2}\right), 2.55$ $\left(3 \mathrm{H}, \mathrm{s}, \mathrm{Hr}-\mathrm{CH}_{3}\right) ;{ }^{13} \mathrm{C}-\mathrm{NMR}(\delta, \mathrm{ppm}): 164.5,164.3,163.3,151.9$, 142.2, 138.6, 134.9, 128.8, 123.7, 122.0, 121.8, 119.2, 118.4, 109.8, 37.7, 36.9, 13.3. ESI-MS ${ }^{(\mathrm{b})} \mathrm{m} / z 420(\mathrm{M}+\mathrm{Na})^{+}$, calculated for $\left(\mathrm{C}_{19} \mathrm{H}_{17} \mathrm{~N}_{5} \mathrm{O}_{2} \mathrm{~S}\right): 379$.

2.7. N-(4-Bromophenyl)-2-\{5-[(2-methyl-1H-benzimidazol-1yl)methyl]-1,3,4-oxadiazol-2-ylthio acetamide (5b). It is a white power which is recrystallized from a mixture of ethanol and water. Yield: $65 \%$; mp 212-213 ${ }^{\circ} \mathrm{C}$. IR $\left(\nu, \mathrm{cm}^{-1}\right): 3173(\mathrm{~N}-$ $\mathrm{H}), 2922(\mathrm{C}-\mathrm{H}), 1674(\mathrm{C}=\mathrm{O}), 1612$ and $1556(\mathrm{C}=\mathrm{N}, \mathrm{C}=\mathrm{C}) ;{ }^{1} \mathrm{H}-$ $\operatorname{NMR}(\delta, \mathrm{ppm}): 10.51(1 \mathrm{H}, \mathrm{s}, \mathrm{N}-\mathrm{H}), 7.52(6 \mathrm{H}, \mathrm{m}, \mathrm{Ar}-\mathrm{H}), 7.17$ $(2 \mathrm{H}, \mathrm{m}, \mathrm{Ar}-\mathrm{H}), 5.80\left(2 \mathrm{H}, \mathrm{s}, \mathrm{CH}_{2}\right), 4.25\left(2 \mathrm{H}, \mathrm{s}, \mathrm{SCH}_{2}\right), 2.55$ $\left(3 \mathrm{H}, \mathrm{s}, \mathrm{Hr}-\mathrm{CH}_{3}\right) ;{ }^{13} \mathrm{C}-\mathrm{NMR}(\delta, \mathrm{ppm}): 164.7,164.2,163.3,151.9$, $142.2,137.9,134.9,131.6,121.9,121.7,121.1,118.4,115.3,109.7$, 37.7, 36.8, 13.3. ESI-MS ${ }^{(\mathrm{b})} \mathrm{m} / z 460(\mathrm{M}+\mathrm{H})^{+}$, calculated for $\left(\mathrm{C}_{19} \mathrm{H}_{16} \mathrm{BrN}_{5} \mathrm{O}_{2} \mathrm{~S}\right): 457 / 459$.

2.8. Synthesis of 5-[(2-Methyl-1H-benzimidazol-1-yl)methyl]4-(4-methylphenyl)-1,2,4-triazol-3-thiol (6). The dissolved acid hydrazide $3(3.06 \mathrm{~g}, 15 \mathrm{mmol})$ in ethanol $(30 \mathrm{~mL})$ and 4-methylphenylisothiocyanate $(2.25 \mathrm{~g}, 15 \mathrm{mmol})$ was added in a flask fitter. The mixture was heated at reflux temperature for an hour. The solution was then cooled down, resulting in a precipitation which was then filtered off and dissolved in $25 \mathrm{~mL} \mathrm{NaOH}(2.0 \mathrm{~mol} / \mathrm{L})$. The solution was refluxed again for 2 hours, cooled, and acidified with diluted hydrochloric acid. The formed precipitate was filtered off, washed with water, and finally recrystallized from ethanol to afford $\mathbf{6}$ as white crystals. Yield 56.4\%; mp 189-190 ${ }^{\circ}$; IR $\left(\nu, \mathrm{cm}^{-1}\right): 3441$ 


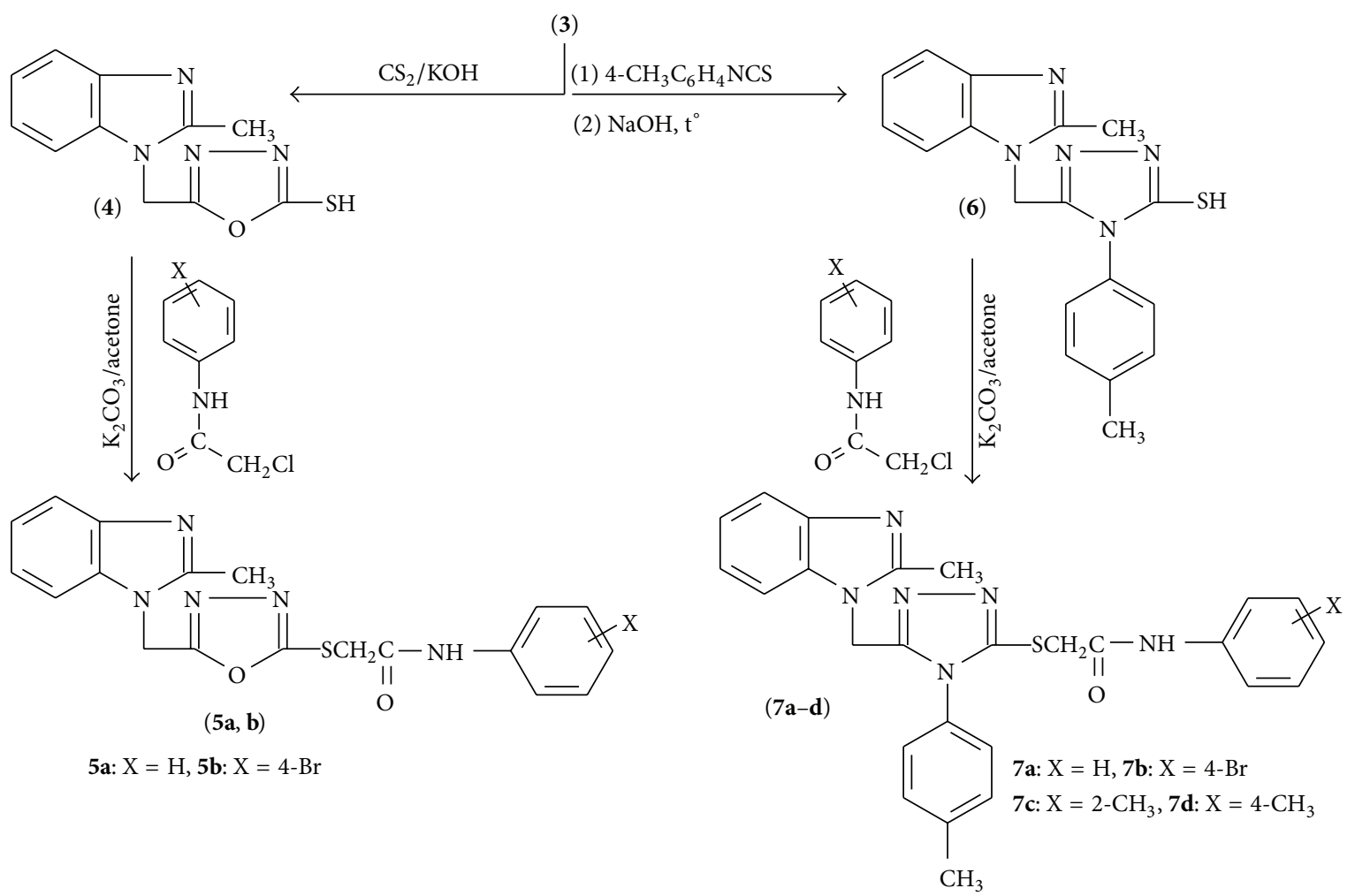

FIGURE 2: Synthetic route for preparation of acetamides containing 1,3,4-oxadiazole heterocycle 5a-b or 1,2,4-triazole heterocycle 7a-d.

$(\mathrm{NH}), 2492(\mathrm{SH}), 1602(\mathrm{C}=\mathrm{N}, \mathrm{C}=\mathrm{C}) ;{ }^{1} \mathrm{H}-\mathrm{NMR}(\delta, \mathrm{ppm})$ : $13.93(1 \mathrm{H}, \mathrm{br}, \mathrm{SH}), 7.49\left(1 \mathrm{H}, \mathrm{d},{ }^{3} J=7.5, \mathrm{Ar}-\mathrm{H}\right), 7.29(2 \mathrm{H}, \mathrm{d}$, $\left.{ }^{3} J=7.5, \mathrm{Ar}-\mathrm{H}\right), 7.23\left(\mathrm{HH}, \mathrm{d},{ }^{3} J=7.5, \mathrm{Ar}-\mathrm{H}\right), 7.16\left(2 \mathrm{H}, \mathrm{d},{ }^{3} J=\right.$ 7.5, Ar-H), $7.11\left(2 \mathrm{H}, \mathrm{dd},{ }^{3} J_{1}={ }^{3} J_{2}=7.0, \mathrm{Ar}-\mathrm{H}\right), 5.31(2 \mathrm{H}, \mathrm{s}$, $\left.\mathrm{CH}_{2}\right), 2.50\left(3 \mathrm{H}, \mathrm{s}, \mathrm{HrCH}_{3}\right), 2.19\left(3 \mathrm{H}, \mathrm{s}, \mathrm{ArCH}_{3}\right) .{ }^{13} \mathrm{C}-\mathrm{NMR}$ $(\delta, \mathrm{ppm}): 168.9,151.9,147.8,142.1,139.5,134.9,130.3,130.0$, $127.7,121.6,121.4,118.2,109.8,33.4,20.7,12.9$. HR-ESI-MS $^{(\mathrm{a})}$ $\mathrm{m} / \mathrm{z} 336.1279(\mathrm{M}+\mathrm{H})$, calculated for $\left(\mathrm{C}_{18} \mathrm{H}_{17} \mathrm{~N}_{3} \mathrm{~S}\right): 335.1205$.

2.9. General Procedure for Synthesis of N-Aryl-2-\{5-[(2-methyl-1H-benzimidazol-1-yl)methyl]-4-(4-methylphenyl)-4H-1,2,4triazol-3-ylthio $\}$ acetamides $(7 \boldsymbol{a}-\boldsymbol{d}) .0 .67$ grams $(2.0 \mathrm{mmol})$ of compound 6 was put into a beaker containing $30 \mathrm{~mL}$ acetone. Then $2.0 \mathrm{mmol}$ of $\mathrm{N}$-aryl chloroacetamide was added along with 0.28 grams $(\sim 2.0 \mathrm{mmol})$ of anhydrous $\mathrm{K}_{2} \mathrm{CO}_{3}$. Then, the mixture was heated to $60^{\circ} \mathrm{C}$ for three hours with constant stirring. After that, the reaction mixture was allowed to cool down to room temperature. The beaker was then placed into an ice bath and cooled to $0^{\circ} \mathrm{C}$ for 30 minutes. Next, the recrystallized compounds $7 \mathbf{a}-\mathbf{d}$ were collected by filtration, washed, and dried. Finally, they were recrystallized from a mixture of ethanol and water.

2.10. 2-\{5-[(2-Methyl-1H-benzimidazol-1-yl)methyl]-4-(4-methylphenyl)-4H-1,2,4-triazol-3-ylthio\}-N-phenylacetamide (7a). White powder. Yield: $60 \%$; $\mathrm{mp} 150-151^{\circ} \mathrm{C}$; $\mathrm{IR}\left(\nu, \mathrm{cm}^{-1}\right): 3425$ (NH), $2931(\mathrm{C}-\mathrm{H}), 1674(\mathrm{C}=\mathrm{O}), 1612(\mathrm{C}=\mathrm{N}, \mathrm{C}=\mathrm{C}) ;{ }^{1} \mathrm{H}-\mathrm{NMR}$ $(\delta, \mathrm{ppm}): 10.28(1 \mathrm{H}, \mathrm{s}, \mathrm{NH}), 7.52\left(2 \mathrm{H}, \mathrm{d},{ }^{3} J=8.0, \mathrm{Ar}-\mathrm{H}\right), 7.46$ $\left(1 \mathrm{H}, \mathrm{d},{ }^{3} \mathrm{~J}=8.0, \mathrm{Ar}-\mathrm{H}\right), 7.30\left(2 \mathrm{H}, \mathrm{dd},{ }^{3} J_{1}={ }^{3} J_{2}=8.0, \mathrm{Ar}-\right.$ $\mathrm{H}) ; 7.27\left(2 \mathrm{H}, \mathrm{d},{ }^{3} \mathrm{~J}=8.0, \mathrm{Ar}-\mathrm{H}\right), 7.13(3 \mathrm{H}, \mathrm{m}, \mathrm{Ar}-\mathrm{H}), 7.11(1 \mathrm{H}$, $\left.\mathrm{dd},{ }^{3} J={ }^{3} J_{2}=8.0, \mathrm{Ar}-\mathrm{H}\right), 7.06(2 \mathrm{H}, \mathrm{m}, \mathrm{Ar}-\mathrm{H}), 5.45(2 \mathrm{H}, \mathrm{s}$, $\left.\mathrm{CH}_{2}\right), 4.10\left(2 \mathrm{H}, \mathrm{s}, \mathrm{CH}_{2}\right), 2.35\left(3 \mathrm{H}, \mathrm{s}, \mathrm{CH}_{3}\right), 2.15\left(3 \mathrm{H}, \mathrm{s}, \mathrm{CH}_{3}\right)$; ${ }^{13}$ C-NMR ( $\delta$, ppm): 165.3, 151.7, 151.6, 151.4, 142.1, 140.3, 138.7, $134.9,130.4,129.4,128.8,126.8,123.5,121.4,121.3,119.1,118.1$, 109.8, 38.4, 36.9, 20.7, 13.0. HR-ESI-MS ${ }^{(\mathrm{a})} \mathrm{m} / z$ 469.1829 (M + $\mathrm{H})^{+}$, calculated for $\left(\mathrm{C}_{26} \mathrm{H}_{24} \mathrm{~N}_{6} \mathrm{OS}\right): 468.1732$.

2.11. N-(4-Bromophenyl)-2-\{5-[(2-methyl-1H-benzimidazol1-yl)methyl]-4-(4-methylphenyl)-4H-1,2,4-triazole-3-ylthio\} acetamide $(7 \boldsymbol{b})$. White powder. Yield: $63.0 \% ; \mathrm{mp} 164-165^{\circ} \mathrm{C}$. IR $\left(\nu, \mathrm{cm}^{-1}\right): 3402(\mathrm{NH}), 2924(\mathrm{C}-\mathrm{H}), 1674(\mathrm{C}=\mathrm{O}), 1620(\mathrm{C}=\mathrm{N}$, $\mathrm{C}=\mathrm{C}) ;{ }^{1} \mathrm{H}-\mathrm{NMR}(\delta, \mathrm{ppm}): 10.41(1 \mathrm{H}, \mathrm{s}, \mathrm{NH}), 7.49(5 \mathrm{H}, \mathrm{m}, \mathrm{Ar}-$ $\mathrm{H}), 7.27\left(2 \mathrm{H}, \mathrm{d},{ }^{3} \mathrm{~J}=8.0, \mathrm{Ar}-\mathrm{H}\right), 7.13(3 \mathrm{H}, \mathrm{m}, \mathrm{Ar}-\mathrm{H}), 7.09(1 \mathrm{H}$, $\left.\mathrm{dd},{ }^{3} J={ }^{3} J_{2}=7.0, \mathrm{Ar}-\mathrm{H}\right), 7.04\left(1 \mathrm{H}, \mathrm{dd},{ }^{3} J={ }^{3} J_{2}=7.0, \mathrm{Ar}-\mathrm{H}\right), 5.45$ $\left(2 \mathrm{H}, \mathrm{s}, \mathrm{CH}_{2}\right), 4.09\left(2 \mathrm{H}, \mathrm{s}, \mathrm{CH}_{2}\right), 2.35\left(3 \mathrm{H}, \mathrm{s}, \mathrm{CH}_{3}\right), 2.15(3 \mathrm{H}, \mathrm{s}$, $\left.\mathrm{CH}_{3}\right) ;{ }^{13} \mathrm{C}-\mathrm{NMR}(\delta, \mathrm{ppm}): 165.6,151.7,151.5,151.4,142.1,140.3$, $138.1,134.9,131.6,130.4,129.4,126.8,121.4,121.3,121.0,118.1$, 115.1, 109.8, 38.4, 36.8, 20.7, 13.0. HR-ESI-MS ${ }^{(\mathrm{a})} \mathrm{m} / z 549.0895$ $(\mathrm{M}+\mathrm{H})^{+}$, calculated for $\left(\mathrm{C}_{26} \mathrm{H}_{23} \mathrm{BrN}_{6} \mathrm{OS}\right): 548.0837$.

2.12. 2-\{5-[(2-Methyl-1H-benzimidazol-1-yl)methyl]-4-(4-methylphenyl)-4H-1,2,4-triazol-3-ylthio\}-N-(2-methylphenyl)acetamide (7c). White powder. Yield: $57 \% ; \mathrm{mp} 153-155^{\circ} \mathrm{C}$. IR ( $v$, $\left.\mathrm{cm}^{-1}\right)$ : 3449 (br, NH), $2924(\mathrm{C}-\mathrm{H}), 1674(\mathrm{C}=\mathrm{O}), 1620(\mathrm{C}=\mathrm{C})$; ${ }^{1} \mathrm{H}-\mathrm{NMR}(\delta, \mathrm{ppm}): 9.63(1 \mathrm{H}, \mathrm{s}, \mathrm{NH}), 7.46\left(1 \mathrm{H}, \mathrm{d},{ }^{3} J=8.0, \mathrm{Ar}-\right.$ $\mathrm{H}), 7.40\left(1 \mathrm{H}, \mathrm{d},{ }^{3} J=8.0, \mathrm{Ar}-\mathrm{H}\right), 7.27\left(2 \mathrm{H}, \mathrm{d},{ }^{3} J=8.0, \mathrm{Ar}-\mathrm{H}\right)$, 
TABLE 1: The minimum inhibitory concentrations (MICs) of the compounds containing 1,3,4-oxadiazole or 1,2,4-triazole heterocycle against bacteria and fungi.

\begin{tabular}{|c|c|c|c|c|c|c|c|c|c|}
\hline \multirow{3}{*}{ Sample } & \multirow{3}{*}{ Concentration $(\mu \mathrm{g} / \mathrm{mL})$} & \multicolumn{8}{|c|}{$\operatorname{MICs}^{*}(\mu \mathrm{g} / \mathrm{mL})$} \\
\hline & & \multicolumn{2}{|c|}{ Bacteria Gr(-) } & \multicolumn{2}{|c|}{ Bacteria Gr(+) } & \multicolumn{2}{|c|}{ Mold } & \multicolumn{2}{|c|}{ Yeast } \\
\hline & & $\mathrm{EC}$ & PA & BS & SA & AN & $\mathrm{FO}$ & SC & $\mathrm{CA}$ \\
\hline 4 & 50 & $(-)$ & $(-)$ & $(-)$ & $(-)$ & 50 & 50 & $(-)$ & $(-)$ \\
\hline $5 \mathbf{a}$ & 50 & $(-)$ & $(-)$ & $(-)$ & $(-)$ & 50 & $(-)$ & $(-)$ & $(-)$ \\
\hline $5 b$ & 50 & $(-)$ & $(-)$ & $(-)$ & $(-)$ & 50 & 50 & $(-)$ & $(-)$ \\
\hline 6 & 50 & $(-)$ & $(-)$ & $(-)$ & $(-)$ & 50 & $(-)$ & $(-)$ & $(-)$ \\
\hline $7 \mathbf{a}$ & 50 & $(-)$ & $(-)$ & $(-)$ & $(-)$ & 50 & $(-)$ & $(-)$ & $(-)$ \\
\hline $7 \mathbf{b}$ & 50 & $(-)$ & $(-)$ & $(-)$ & $(-)$ & 50 & 50 & $(-)$ & $(-)$ \\
\hline $7 c$ & 50 & $(-)$ & $(-)$ & $(-)$ & $(-)$ & 50 & $(-)$ & $(-)$ & $(-)$ \\
\hline $7 d$ & 50 & $(-)$ & $(-)$ & $(-)$ & $(-)$ & 50 & $(-)$ & $(-)$ & $(-)$ \\
\hline
\end{tabular}

*EC: Escherichia coli, PA: Pseudomonas aeruginosa, BS: Bacillus subtilis, SA: Staphylococcus aureus, AN: Aspergillus niger, FO: Fusarium oxysporum, SC: Saccharomyces cerevisiae, and CA: Candida albicans.

$7.19\left(1 \mathrm{H}, \mathrm{d},{ }^{3} \mathrm{~J}=\right.$ 8.0, Ar-H), 7.14 (4H, m, Ar-H), 7.08 (1H, dd, ${ }^{3} J={ }^{3} J_{2}=7.0$, Ar-H), $7.08\left(1 \mathrm{H}, \mathrm{dd},{ }^{3} J={ }^{3} J_{2}=7.0\right.$, Ar-H $), 5.47$ $\left(2 \mathrm{H}, \mathrm{s}, \mathrm{CH}_{2}\right), 4.12\left(2 \mathrm{H}, \mathrm{s}, \mathrm{CH}_{2}\right), 2.36\left(3 \mathrm{H}, \mathrm{s}, \mathrm{CH}_{3}\right), 2.15(6 \mathrm{H}, \mathrm{s}$, $\left.\mathrm{CH}_{3}\right) ;{ }^{13} \mathrm{C}-\mathrm{NMR}(\delta, \mathrm{ppm}): 165.6,151.7,151.6,151.4,142.1,140.3$, $135.9,134.9,131.3,130.3,130.2,129.4,126.8,125.9,125.2,124.4$, $121.4,121.3,118.1,109.8,36.3,30.6,20.7,17.7,13.0$. HR-ESI$\mathrm{MS}^{(\mathrm{a})} \mathrm{m} / z 483.1962(\mathrm{M}+\mathrm{H})^{+}$, calculated for $\left(\mathrm{C}_{27} \mathrm{H}_{26} \mathrm{~N}_{6} \mathrm{OS}\right)$ : 482.1889 .

2.13. 2-\{5-[(2-Methyl-1H-benzimidazol-1-yl)methyl]-4-(4-methylphenyl)-4H-1,2,4-triazole-3-ylthio\}-N-(4-methylphenyl)acetamide $(7 \boldsymbol{d})$. White powder. Yield: $64.0 \%$; mp $159-160^{\circ} \mathrm{C}$. IR $\left(\nu, \mathrm{cm}^{-1}\right): 3441(\mathrm{~N}-\mathrm{H}), 3063,2924(\mathrm{C}-\mathrm{H}), 1674(\mathrm{C}=\mathrm{O}) ;{ }^{1} \mathrm{H}-$ $\operatorname{NMR}(\delta, \mathrm{ppm}): 10.18(1 \mathrm{H}, \mathrm{s}, \mathrm{NH}), 7.46\left(1 \mathrm{H}, \mathrm{d},{ }^{3} J=8.0\right.$, Ar$\mathrm{H}), 7.40\left(2 \mathrm{H}, \mathrm{d},{ }^{3} \mathrm{~J}=8.0, \mathrm{Ar}-\mathrm{H}\right), 7.28\left(2 \mathrm{H}, \mathrm{d},{ }^{3} \mathrm{~J}=8.0, \mathrm{Ar}-\mathrm{H}\right)$, $7.13(3 \mathrm{H}, \mathrm{m}, \mathrm{Ar}-\mathrm{H}), 7.09$ (3H, m, Ar-H), 7.04 (1H, dd, ${ }^{3} J={ }^{3} J_{2}$ = 7.0, Ar- $\mathrm{H}), 5.45\left(2 \mathrm{H}, \mathrm{s}, \mathrm{CH}_{2}\right), 4.08\left(2 \mathrm{H}, \mathrm{s}, \mathrm{CH}_{2}\right), 2.35(3 \mathrm{H}$, $\left.\mathrm{s}, \mathrm{CH}_{3}\right), 2.24\left(3 \mathrm{H}, \mathrm{s}, \mathrm{CH}_{3}\right), 2.15\left(3 \mathrm{H}, \mathrm{s}, \mathrm{CH}_{3}\right) ;{ }^{13} \mathrm{C}-\mathrm{NMR}(\delta$, ppm): 165.0, 151.7, 151.6, 151.4, 142.1, 140.2, 136.2, 134.9, 132.4, $130.3,129.4,129.1,126.8,121.4,121.3,119.1,118.1,109.8,36.9$, 30.6, 20.7, 20.4, 13.0; HR-ESI-MS ${ }^{(\mathrm{a})} \mathrm{m} / z 483.1933(\mathrm{M}+\mathrm{H})^{+}$, calculated for $\left(\mathrm{C}_{27} \mathrm{H}_{26} \mathrm{~N}_{6} \mathrm{OS}\right): 482.1889$.

\section{Results and Discussion}

Reaction of 2-methyl-1H-benzimidazole (1) with ethyl chloroacetate in the presence of anhydrous potassium carbonate followed by the reaction with hydrazine hydrate gave 2(2-methyl-1H-benzimidazol-1-yl)acetohydrazide (3), the key intermediate compound used for the synthesis of both series of the heterocycles. Thus, when compound 3 was treated with carbon disulfide and potassium hydroxide according to literature [9], 5-[2-(2-methylbenzimidazol-1-yl)methyl]$[1,3,4]$-oxadiazol-2-thiole (4) was obtained. Furthermore, it is found that the melting point of three synthesized intermediate compounds $(1,3$, and 4$)$ quite matches the value found in the earlier reports $[6,9]$. However, melting point in the case of compound $\mathbf{2}$ (ethyl (2-methylbenzimidazol-1-yl)acetate) is $114^{\circ} \mathrm{C}$, lower than the value of $184-186^{\circ} \mathrm{C}$ according to [6].
Note that the melting point of compound $\mathbf{2}$ was measured lower than the melting point of compound 1, while [6] provided the inverse data. Our result may be more reasonable because compound $\mathbf{2}$ is an ester without any hydrogen bonds. Hence, it is surely melted at lower temperature. In contrast, compound 1 forms extramolecular hydrogen bonds as shown in the publication of Seliger and Žagar [20]. So, the melting point of compound 1 should be higher.

General method for the formation of 4-aryl-1,2,4-triazol3-thiol is refluxing hydrazide with aryl isothiocyanates in ethanol to give the corresponding thiosemicarbazide derivatives, subsequently treating the thiosemicarbazide with sodium hydroxide solution at refluxed temperature $[7,14]$. So the product obtained by reaction of 3 with 4-methylphenyl isothiocyanate was refluxed in sodium hydroxide solution to give 5-[(2-methyl-1H-benzimidazol-1-yl)methyl]-4-(4-methylphenyl)-1,2,4-triazol-3-thiol (6). Furthermore, the treatment of compound $\mathbf{4}$ or $\mathbf{6}$ with $\mathrm{N}$-aryl-2-chloroacetamide in the presence of potassium carbonate gives, respectively, $S$-substituted 1,3,4-oxadiazole or S-substituted 1,2,4-triazole derivatives.

While the structures of (1-4) compounds were confirmed by comparison of their physical and spectral data with the reported ones [4-9], the structures of other compounds were established based on analysis of the spectral data. Formation of heterocycles $\mathbf{4}$ and $\mathbf{6}$ by cyclization of hydrazide 3 was confirmed by a lack of stretching band of $\mathrm{C}=\mathrm{O}$ at $1658 \mathrm{~cm}^{-1}$ in the IR spectra of the products. Besides, there was a downfield shift of signals of the $-\mathrm{CH}_{2}-$ group connected to benzimidazole heterocycle in the ${ }^{1} \mathrm{H}$-NMR spectrum of 4 or 6 compounds in comparison with signal of the $-\mathrm{CH}_{2}-$ group in the ${ }^{1} \mathrm{H}-\mathrm{NMR}$ spectrum of compound 4 . The compounds 5a-b and $7 \mathbf{a}-\mathbf{d}$ showed the $\mathrm{CONH}$ group band around $1675 \mathrm{~cm}^{-1}$ in their IR spectra. The ${ }^{1} \mathrm{H}$-NMR spectra of these compounds showed the signal of the $\mathrm{CONH}$ proton between 9.63 and $10.51 \mathrm{ppm}$ while in the ${ }^{13} \mathrm{C}$-NMR spectra appeared the signal of carbon carbonyl between 164.5 and $165.6 \mathrm{ppm}$. In the ESI-MS of the compounds, all of the molecular ion peaks were in accordance with their expected formula. 
Compounds containing 1,3,4-oxadiazole heterocycle (4 and $5 \mathbf{a}-\mathbf{b})$ or 1,2,4-triazole (6 and $7 \mathbf{a}-\mathbf{d})$ were examined for antimicrobial activity against Escherichia coli, Pseudomonas aeruginosa (Gram-negative bacteria); Bacillus subtilis, Staphylococcus aureus (Gram-positive bacteria); Aspergillus niger, Fusarium oxysporum (mold) and Saccharomyces cerevisiae, Candida albicans (yeast). It can be seen in Table 1 that all the compounds exhibited activity against Aspergillus niger; compounds $\mathbf{4}, \mathbf{5 b}$, and $\mathbf{7 b}$ exhibited activity against Fusarium oxysporum while all of the tested compounds were generally inefficient against bacteria and yeast.

\section{Conclusions}

Seven new compounds including two $N$-aryl-2-\{5-[(2-methyl-1H-benzimidazol-1-yl)methyl]-1,3,4-oxadiazol-2-yl\}sulfanylacetamides (5a-b), 5-[(2-methyl-1H-benzimidazol-1-yl) methyl]-4-(4-methylphenyl)-1,2,4-triazol-3-thiol (6), and four $N$-aryl-2-\{5-[(2-methyl-1H-benzimidazol-1-yl)methyl]4-(4-methylphenyl)-4H-1,2,4-triazol-3-ylthio\}acetamides (7a-d) were successfully synthesized. The structures of the compounds were determined by IR, MS, ${ }^{1} \mathrm{H}-\mathrm{NMR}$, and ${ }^{13} \mathrm{C}$ NMR spectral data. All of the compounds containing 1,3,4oxadiazole or 1,2,4-triazole heterocycle exhibited activity against Aspergillus niger; 5-[2-(2-methylbenzimidazol-1-yl) methyl]-[1,3,4]-oxadiazole-2-thiol (4) and two acetamides containing $N$-(4-bromophenyl)acetamide moiety exhibited activity against Fusarium oxysporum.

\section{Conflict of Interests}

The authors declare that there is no conflict of interests regarding the publication of this paper.

\section{References}

[1] A. Husain, M. M. Varshney, M. Rashid, R. Mishra, and A. Akhter, "Benzimidazole: a valuable insight into the recent advances and biological activities," Journal of Pharmacy Research, vol. 4, no. 2, pp. 413-419, 2011.

[2] R. Walia, M. Hedaitullah, S. F. Naaz, K. Iqbal, and H. S. Lamba, "Benzimidazole derivatives-an overview," International Journal of Research in Pharmacy and Chemistry, vol. 1, no. 3, pp. 565-574, 2011.

[3] A. A. H. Abdel-Rahman, I. F. Nassar, I. M. H. El-Kattan, A. A. Aly, M. S. Behalo, and N. M. Abdelwahed, "Synthesis and antimicrobial evaluation of thioglycosides and acyclic C-nucleosides of 2-methylbenzimidazole," Der Pharma Chemica, vol. 5, pp. 210-217, 2013.

[4] K. F. Ansari and C. Lal, "Synthesis, physicochemical properties and antimicrobial activity of some new benzimidazole derivatives," European Journal of Medicinal Chemistry, vol. 44, no. 10, pp. 4028-4033, 2009.

[5] K. F. Ansari and C. Lal, "Synthesis and evaluation of some new benzimidazole derivatives as potential antimicrobial agents," European Journal of Medicinal Chemistry, vol. 44, no. 5, pp. 2294-2299, 2009.

[6] K. F. Ansari and C. Lal, "Synthesis and biological activity of some heterocyclic compounds containing benzimidazole and beta-lactam moiety," Journal of Chemical Sciences, vol. 121, no. 6, pp. 1017-1025, 2009.

[7] K. F. Ansari, C. Lal, and R. K. Khitoliya, "Synthesis and biological activity of some triazole-bearing benzimidazole derivatives," Journal of the Serbian Chemical Society, vol. 76, no. 3, pp. 341$352,2011$.

[8] G. Ayhan-Kılcıgil, M. Tunçbilek, N. Altanlar, and H. Göker, "Synthesis and antimicrobial activity of some new benzimidazole carboxylates and carboxamides," Il Farmaco, vol. 54, no. 8, pp. 562-565, 1999.

[9] R. Dua, S. K. Sonwane, S. K. Srivastava, and S. D. Srivastava, "Conventional and greener approach for the synthesis of some novel substituted-4-oxothiazolidine and their 5-arylidene derivatives of 2-methyl-benzimidazole: antimicrobial activities," Journal of chemical and Pharmaceutical research, vol. 2, pp. 415-423, 2010.

[10] A. H. El-Masry, H. H. Fahmy, and S. H. Ali Abdelwahed, "Synthesis and antimicrobial activity of some new benzimidazole derivatives," Molecules, vol. 5, no. 12, pp. 1429-1438, 2000.

[11] N. R. Candeias, L. C. Branco, P. M. P. Gois, C. A. M. Afonso, and A. F. Trindade, "More sustainable approaches for the synthesis of n-based heterocycles," Chemical Reviews, vol. 109, no. 6, pp. 2703-2802, 2009.

[12] C. S. De Oliveira, B. F. Lira, J. M. Barbosa-Filho, J. G. F. Lorenzo, and P. F. De Athayde-Filho, "Synthetic approaches and pharmacological activity of 1,3,4-oxadiazoles: a review of the literature from 2000-2012," Molecules, vol. 17, no. 9, pp. 1019210231, 2012.

[13] J. Sharma, S. Ahmad, and M. S. Alam, "Bioactive triazoles: a potential review," Journal of Chemical and Pharmaceutical Research, vol. 4, no. 12, pp. 5157-5164, 2012.

[14] R. V. Patel, P. K. Patel, P. Kumari, D. P. Rajani, and K. H. Chikhalia, "Synthesis of benzimidazolyl-1,3,4-oxadiazol2ylthio-N-phenyl (benzothiazolyl) acetamides as antibacterial, antifungal and antituberculosis agents," European Journal of Medicinal Chemistry, vol. 53, pp. 41-51, 2012.

[15] A. Sandala, R. Suthakaran, A. Vema, A. Ravindernath, and K. S. K. R. Patnaik, "Molecular p prediction, docking studies and synthesis of 5-benzimidazole-1-yl-methyl-[1,3,4] oxadiazole-2thiol and their derivatives," International Journal of Research and Development in Pharmacy and Life Sciences, vol. 2, pp. 432-438, 2013.

[16] H. A. Abdel-Fattah, A. S. El-Etrawy, and N. R. M. Gabr, "Synthesis and biological evaluation of some new 1,3,4-oxa, thiadiazole and 1,2,4-triazole derivatives attached to benzimidazole," International Journal of Pharmaceutical Chemistry, vol. 4, no. 3, pp. 112-118, 2014.

[17] N. T. Cong, H. T. Nhan, L. Van Hung, T. D. Thang, and P.-C. Kuo, "Synthesis and antibacterial activity of analogs of 5-arylidene-3-(4-methylcoumarin-7-yloxyacetylamino)-2-thioxo-1,3-thiazolidin-4-one," Molecules, vol. 19, pp. 13577-13586, 2014.

[18] S. Ganguly, S. Murugesan, and G. Maga, "Synthesis, evaluation and molecular modeling studies of some novel tetrahydroisoquinoline derivatives targeted at the HIV-1 reverse transcriptase," Indian Journal of Heterocyclic Chemistry, vol. 18, no. 4, pp. 357-360, 2009. 
[19] M. A. Al-Sha'er, "Evaluation of antimicrobial activities of synthesized pyridinium derivatives," Der Pharma Chemica, vol. 6, no. 4, pp. 261-291, 2014.

[20] J. Seliger and V. Žagar, "Nuclear quadrupole resonance study of hydrogen bonds in solid 2-methylbenzimidazole and 5,6dimethylbenzimidazole," The Journal of Physical Chemistry C, vol. 117, no. 39, pp. 20193-20200, 2013. 

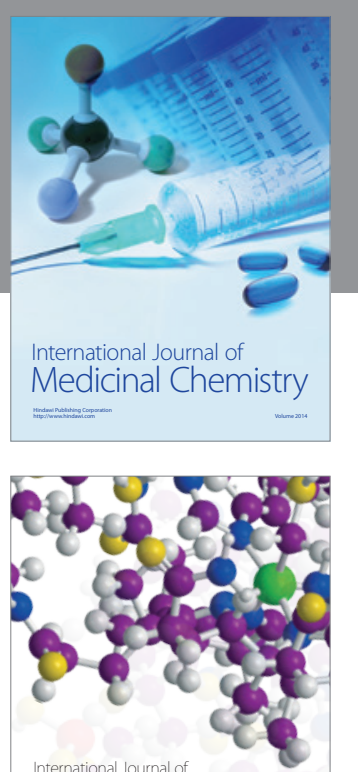

Carbohydrate Chemistry

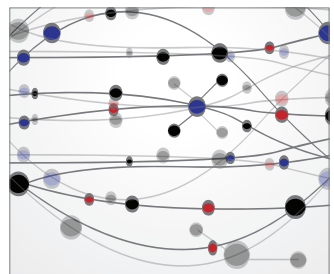

The Scientific World Journal
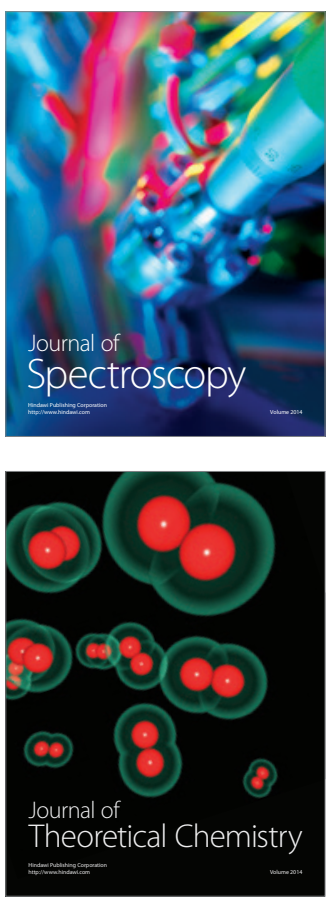
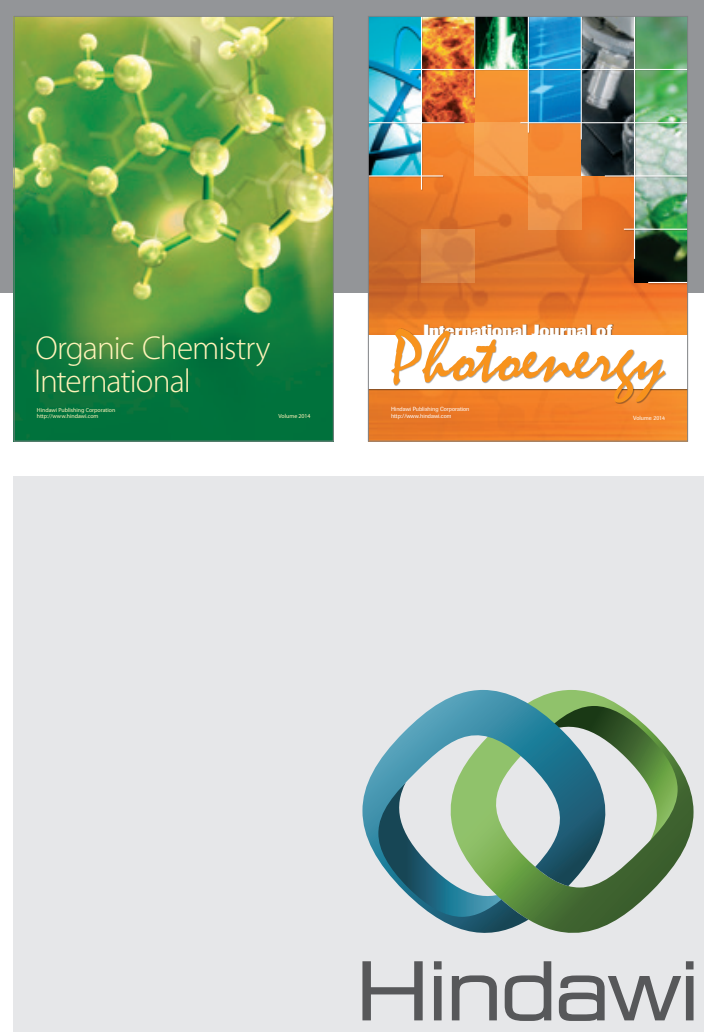

Submit your manuscripts at

http://www.hindawi.com

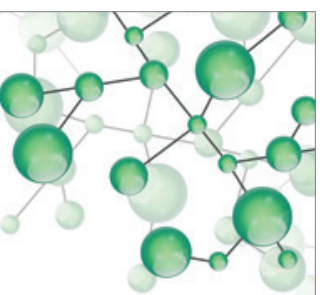

International Journal of

Inorganic Chemistry

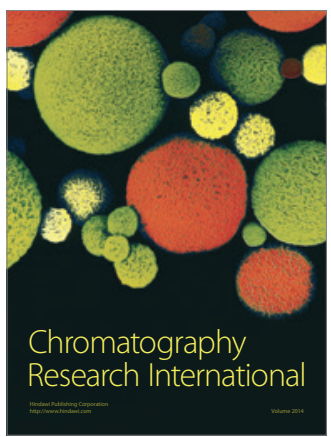

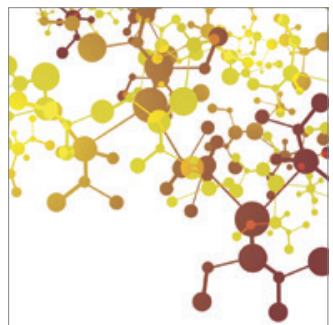

Applied Chemistry
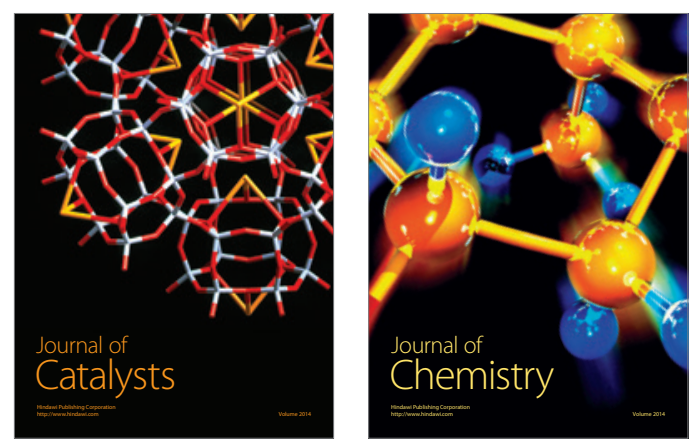
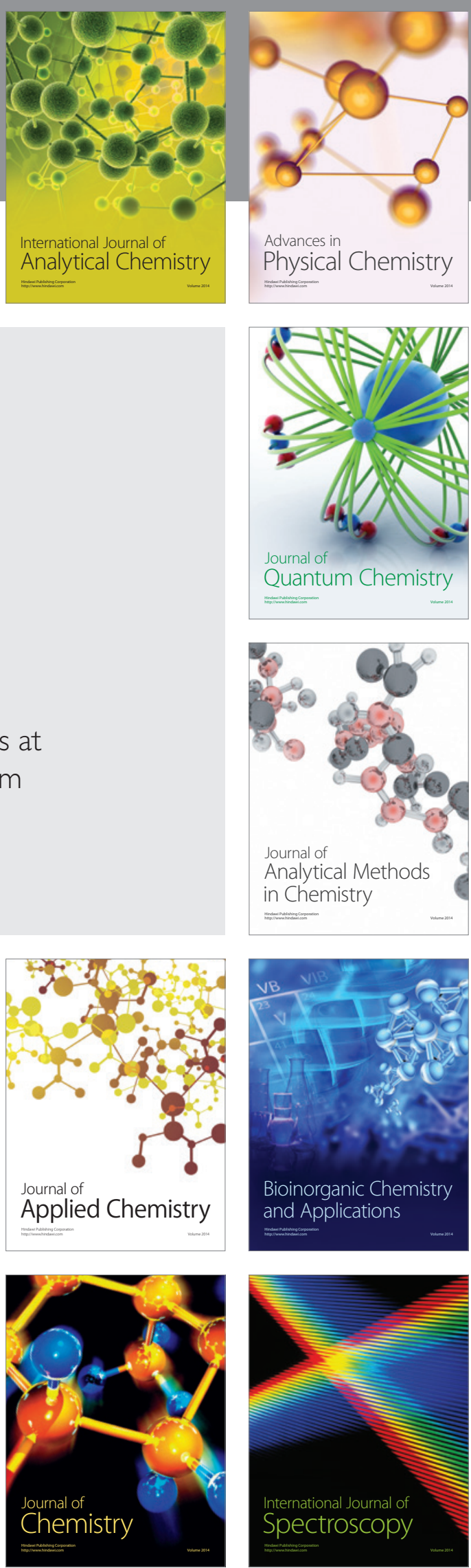